\title{
Dried flower powder combination of Clitoria ternatea and Punica granatum demonstrated analogous anti-hyperglycemic potential as compared with standard drug metformin: In vivo study in Sprague Dawley rats
}

\author{
Sachin P. Borikar ${ }^{1 *}$, Nilesh G. Kallewar ${ }^{2}$, Debarshi Kar Mahapatra ${ }^{3}$, Nitin G. Dumore \\ ${ }^{1}$ Department of Pharmacology, Dadasaheb Balpande College of Pharmacy, Nagpur, India. \\ ${ }^{2}$ Department of Quality Assurance, Shrimati Kishoritai Bhoyar College of Pharmacy, Nagpur, India. \\ ${ }^{3}$ Department of Pharmaceutical Chemistry, Dadasaheb Balpande College of Pharmacy, Nagpur, India. \\ ${ }^{4}$ Department of Pharmacology, Dadasaheb Balpande College of Diploma in Pharmacy, Nagpur, India.
}

\begin{tabular}{l}
\hline ARTICLE INFO \\
\hline Received on: 13/05/2018 \\
Accepted on: 08/10/2018 \\
Available online: 30/11/2018 \\
\\
Key words: \\
Hypoglycemic, Clitoria \\
ternatea, Punica granatum, \\
flower, powder, alloxan.
\end{tabular}

\section{INTRODUCTION}

The diabetes mellitus type-2 (DMT-2) is among the highly escalating disease that is expected to affect nearly 400 million people across the globe by the end of 2030 (Mahapatra et al., 2015). In DMT-2, the control of post-prandial surge is the most imperative requirement for the management of metabolic disturbances (Mahapatra and Bharti, 2018). The current pharmacotherapeutic strategy for DMT-2 involves managing the uncontrolled pace of disease progression every year

\section{*Corresponding Author}

Sachin P. Borikar, Department of Pharmacology, Dadasaheb Balpande College of Pharmacy, Nagpur, India. E-mail: sachinborikar@gmail.com
(Mahapatra and Bharti, 2017). At present, several classes of antidiabetic drugs of synthetic origin are available like biguanides (metformin), sulfonylureas (glipizide, glyburide, etc.), metaglinide (repaglinide, nateglinide, etc.), thiazolidinedione (pioglitazone, rosiglitazone, etc.), cellulose-type (acarbose, miglitol, etc.) and so on, which work by various pharmacological mechanisms like protein tyrosine phosphatase $1 \mathrm{~B}$, peroxisome proliferatoractivated receptor- $\gamma$, dipeptidyl peptidase- 4 , aldose reductase, and $\alpha$-glucosidase (Chhajed et al., 2017; Godbole et al., 2017). However, the inclined trend toward herbal-based anti-diabetic agents among the developing nations owing to their safety and reduced side-effects has compelled the researchers to explore the hidden potentials of herbs and shrubs of Mother Nature (Mahapatra and Bharti, 2016). The increasing interest of herbal 
products among the patient population has also revolutionized the traditional ethnopharmacological aspects (Kamble et al., 2017). At present, the plant extracts or pure phytoconstituents are studied for diverse characteristics of effective control of blood glucose level, increased peripheral uptake of carbohydrates, offer repression of hyperglycemic raise, reduction or maintenance of body weight (obesity-related issues), and effectual management of serum triglyceride levels (Askary-Ashtiani et al., 2016; Mahapatra et al., 2017).

While processing toward the direction, it has been observed in various clinical database that the flowers and seeds of Clitoria ternatea (Family: Fabaceae) (Daisy and Rajathi, 2009; Daisy et al., 2009; Verma et al., 2013; Kalyan et al., 2011; Kavitha and Premalakshmi, 2012; Sharma and Majumder, 1990) and Punica granatum (Family: Punicaceae) (Bagri et al., 2009; Das and Barman, 2012; Das et al., 2001; Huang et al., 2005; Jafri et al., 2000; Khalil, 2004; Li et al., 2005; Radhika et al., 2001) have been reported to possess adequate anti-hyperglycemic activity, individually. However, the role of both the dried plant flower extract powder in combination was never explored in exhibiting the hypoglycemic effect. In the present study, dried flower powder of $C$. ternatea and $P$. granatum was screened in combination for their anti-hyperglycemic activity in an alloxan-induced diabetic rat model, employing the standard drug metformin hydrochloride.

\section{MATERIALS AND METHODS}

\section{Chemicals}

The standard drug metformin hydrochloride was obtained in the form of generous gift sample from Zim Laboratories Ltd., Nagpur. The alloxan monohydrate was procured from HiMedia Ltd., India. The other chemicals used during the experiment were of analytical grade and purchased from HiMedia Ltd., India.

\section{Instruments}

Shimadzu $^{\circledR}$ electronic balance (Model: AUW220D, Japan) was employed in weighing purpose. The Glucose strips $\left(\right.$ One Touch ${ }^{\mathrm{TM}}$ ), obtained from the local Pharmacy, were used for monitoring the blood glucose level.

\section{Animals}

The potentials of the dried flower powder in reducing blood glucose level were screened on Sprague Dawley rats, having an average weight of 150-200 g, aged 5-6 weeks, kept in clean polypropylene cage under controlled environment $\left(25^{\circ} \mathrm{C}-26^{\circ} \mathrm{C}\right.$, humidity $50 \%-55 \%$, and 12 hours light/dark cycle) in animal house, and given free access to water and fed them with standard rodent pellets. The Departmental Ethical Committee permission and CPCSEA approval (853/AC/04/CPCSEA/2009) were obtained in carrying out this experiment.

\section{Collection and authentication of plant material}

The $C$. ternatea and $P$. granatum flowers were freshly gathered in the month of September from the Institute's Medicinal Plant Garden. The obtained plants and their flowers were authenticated (Voucher No: 9260, 9261) by Dr. Dongarwar, Department of Botany, Rashtrasant Tukdoji Maharaj Nagpur University, Nagpur, Maharashtra, India.

\section{Extraction protocol}

The flowers of $C$. ternatea and $P$. granatum were dried for the duration of 2 weeks and then coarse powder was attained by grinding. About $200 \mathrm{~g}$ of content was macerated thoroughly using water-free methanol for 15 days. Utilizing a rotator vacuum evaporator, the solvent was evaporated to dryness and the solid dark violet color mass (yield: 8.4\%), in the case of C. ternatea, and solid dark brown color mass (yield: 9.6\%) were obtained for $P$. granatum. The solid mass was further grounded and converted into fine powder.

\section{Pharmacological screening}

\section{Oral acute toxicity studies}

The acute toxicity studies were performed in the plant dried flower powder to determine the minimum concentration of drug required for therapeutic action and maximum in vivo safety limit. In the Sprague Dawley rats, the dose was administrated with rapidly escalating doses from 5 to $5,000 \mathrm{mg} / \mathrm{kg}$. According to the OECD guideline 423 , the $\mathrm{LD}_{50}$ values were determined to find out the therapeutic index (Kanhed et al., 2016).

\section{Anti-hyperglycemic activity screening}

The hypoglycemic potentials of the dried flower powder were evaluated using alloxan-induced diabetes mellitus rats. The normoglycemic rats were starved for 16 hours by injecting alloxan monohydrate $(150 \mathrm{mg} / \mathrm{kg} \mathrm{bw})$ via the intraperitoneal route after dissolving in physiological saline. Subsequently, the rats were treated with $20 \%$ glucose solution after 6 hours via the oral route. The rats were kept on $5 \%$ glucose solution for the next 24 hours to prevent hypoglycemia. After 48 hours of alloxan administration, the rats presenting the blood glucose level $>250 \mathrm{mg} / \mathrm{dl}$ were considered as hyperglycemic and included in the study (six in number/group). The dried flower powder of $C$. ternatea and $P$. granatum in the dose of 100 and $200 \mathrm{mg} / \mathrm{kg}$ bw and the blood glucose level was verified at the end of 1,3 , and 5 hours after the oral administration. According to the AUC method, the potential of the dried flower powder in reducing the blood glucose level was computed as \% anti-hyperglycemic activity (Kuhite et al., 2017).

\section{Statistical analysis}

The procedure was performed in a triplicate manner. The results were obtained from six animals in each group and expressed as mean \pm SEM. The obtained results were statistically evaluated using Prism v5.0. Two-way analysis of variance followed by Bonferroni post-hoc tests to compare the data. The $p$-value of $<0.05$ was considered to be statistically significant.

\section{RESULTS AND DISCUSSION}

\section{Determination of $\mathrm{LD}_{50}$ values}

As per the OECD guidelines, the minimum dose that can bring about the maximum anti-hyperglycemic effect for each plant dried flower powder through oral route for repetitive administration was determined. In the dose range of 5 to $5,000 \mathrm{mg} / \mathrm{kg}$ of both the plant dried powder, two doses 100 and $200 \mathrm{mg} / \mathrm{kg}$ bw were selected for screening the in vivo anti-diabetic potentials in Sprague Dawley rats, where no toxic signs or symptoms were detected along with mortality. 


\section{Hypoglycemic potential}

The oral administration of dried flowers powder of $C$. ternatea and $P$. granatum combination facilitated antihyperglycemic effect in alloxan-induced diabetic rats $\left[F_{(5,72)}=17.35, p<0.0001\right]$. In Group 1, the control rats demonstrated a substantial rise in the blood glucose level from 349.5 to 478.9 $\mathrm{mg} / \mathrm{dl}$ over the period of 5 hours. The administration of alloxan monohydrate results in a decreased insulin release from the $\beta$ cells due to the massive destruction in the islets of Langerhans. In Group 2 , the standard drug metformin at $120 \mathrm{mg} / \mathrm{kg}$ dose significantly suppressed the hyperglycemic rise in the Sprague Dawley rats from 396.8 to $102.8 \mathrm{mg} / \mathrm{dl}$. The oral administration of the dried flower powders of $C$. ternatea and $P$. granatum represented an impressive decrease in the alloxan-induced elevated blood glucose level in rats. In the Group 3, C. ternatea $(200 \mathrm{mg} / \mathrm{kg})$ and P. granatum $(200 \mathrm{mg} / \mathrm{kg})$ presented a time-dependent reduction of plasma glucose level from 401.7 to $198.2 \mathrm{mg} / \mathrm{dl}$, which signifies the potential of the combination of plant extracts. The combination exhibited a comparable anti-diabetic perspective than that of metformin, the standard anti-hyperglycemic drug. In the Group 4, C. ternatea $(100 \mathrm{mg} / \mathrm{kg})$ and $P$. granatum $(100 \mathrm{mg} / \mathrm{kg})$ displayed a comparable decrease in the blood plasma glucose level from 399.8 to $207.1 \mathrm{mg} / \mathrm{dl}$ (Table 1). However, the study highlighted that doubling the dose of C. ternatea resulted in a marginal enhancement in the glucose-lowering potential. The hypoglycemic activity may be exerted due to the flavonoid principles and the alkaloids present in the plant materials (Borikar et al., 2018). It might be predicted that the anti-hyperglycemic mechanism involves potentiating the insulin secretion from the $\beta$-cell or by enhancing the transport of blood glucose from plasma to the peripheral tissues (Borikar et al., 2017). The post-hoc Bonferroni multiple comparison revealed that metformin, C. ternatea (100 and $200 \mathrm{mg} / \mathrm{kg})$, P. granatum (100 $\mathrm{mg} / \mathrm{kg}$ ) significantly decreased the blood glucose level after 3 hours $(p<0.001)$ and 5 hours $(p<0.001)$. The $P$. granatum $(200 \mathrm{mg} / \mathrm{kg})$ significantly decreased the blood glucose level after 1 hour $(p<0.01)$, 3 hours $(p<0.001)$, and 5 hours $(p<0.001)$ (Fig. 1).

In the reported studies, the hypoglycemic screening of $P$. granatum flower hydroalcoholic extract in fasted Zucker diabetic fatty rats showed a potent $\alpha$-glucosidase inhibition $\left(\mathrm{IC}_{50}\right.$ of 1.8 $\mu \mathrm{g} / \mathrm{ml})$, peroxisome proliferator-activated receptor- $\gamma$ activation, and improvement in glucose sensitivity at peripheral milieu which effectively cause reduction in the blood glucose level from 360 to

Table 1. Anti-hyperglycemic potential of combined dried flower powder of C. ternatea and P. granatum.

\begin{tabular}{|c|c|c|c|c|c|}
\hline \multirow{2}{*}{ Groups } & \multirow{2}{*}{ Dose (mg/kg) } & \multicolumn{4}{|c|}{ Blood glucose level (mg/dl) } \\
\hline & & 0 hour & 1 hour & 3 hours & 5 hours \\
\hline Saline & $1 \mathrm{ml}$ & $349.5 \pm 11.74$ & $372.3 \pm 13.41$ & $340.6 .3 \pm 12.64$ & $478.9 \pm 10.56$ \\
\hline Metformin $\mathrm{HCl}$ & 120 & $396.8 \pm 4.23$ & $314.4 \pm 7.39$ & $189.3 \pm 5.58$ & $102.8 \pm 6.81$ \\
\hline $\begin{array}{l}\text { Combined dried flower powder of } \\
\text { C. ternatea and } P \text {. granatum }\end{array}$ & 400 & $401.7 \pm 8.44$ & $379.7 \pm 6.67$ & $209.6 \pm 9.82$ & $198.2 \pm 7.13$ \\
\hline $\begin{array}{l}\text { Combined dried flower powder of } \\
\text { C. ternatea and } P \text {. granatum }\end{array}$ & 200 & $399.8 \pm 7.66$ & $378.9 \pm 4.51$ & $268.1 \pm 5.96$ & $207.1 \pm 5.87$ \\
\hline
\end{tabular}

$n=6 ; \mathrm{ED}_{50}$ values were found to be 100,200 , and $400 \mathrm{mg} / \mathrm{kg}$ bw; $p<0.05$.

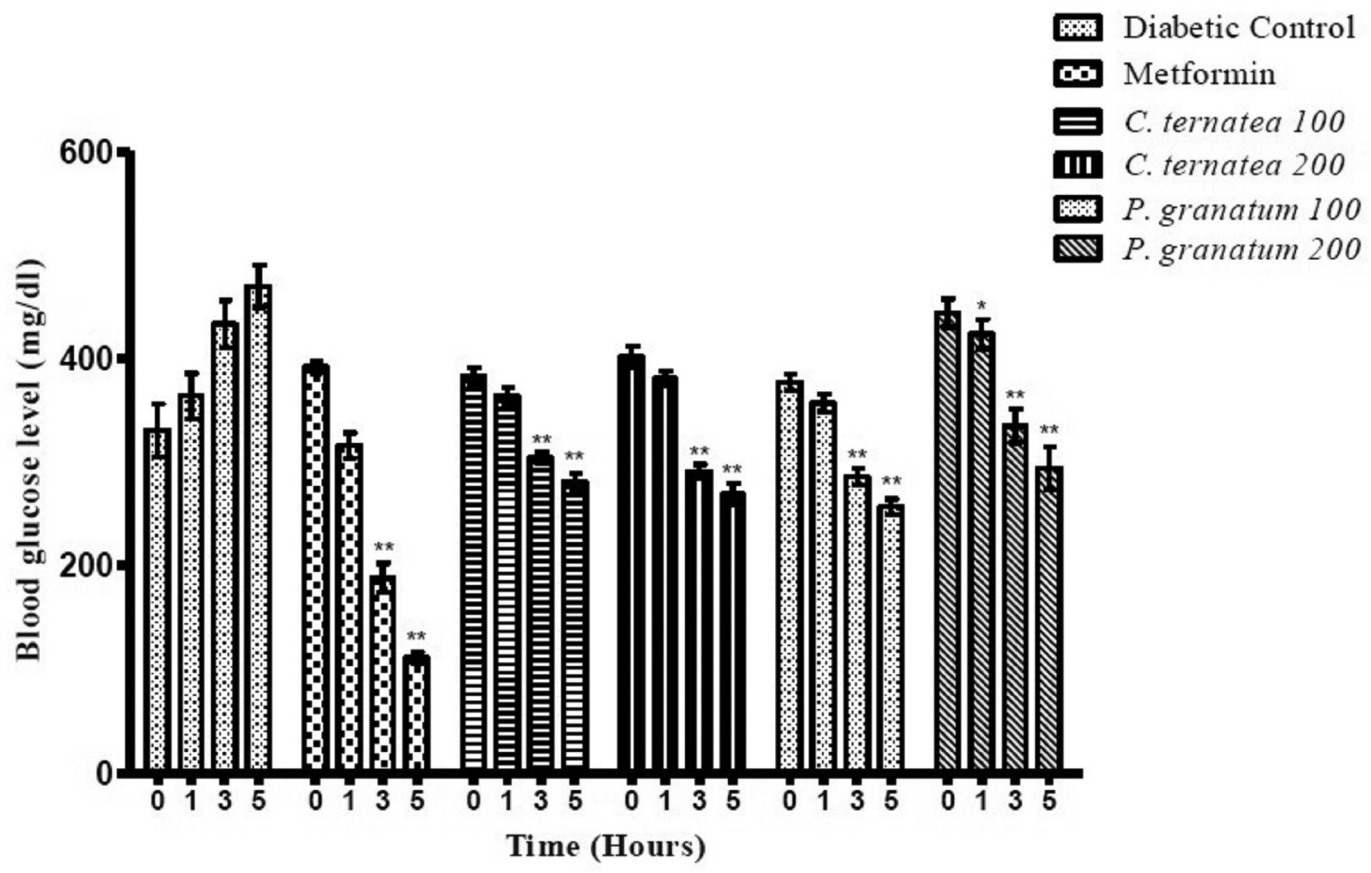

Figure 1. Effects of C. ternatea and P. granatum dried flowers powder in alloxan-induced diabetic rats. 
$240 \mathrm{mg} / \mathrm{dl}$ (Huang et al., 2005; Jafri et al., 2000; Li et al., 2005). The methanolic combined extracts of C. ternatea and P. granatum demonstrated a swift decrease in the blood glucose level from 400 to $200 \mathrm{mg} / \mathrm{dl}$ than the single plant extract, which justified the synergistic potential of the therapeutics. In addition to it, the extract expressed an effectual modulation of glutathione peroxidase, glutathione reductase, catalase, superoxide dismutase, and glutathione-S-transferase which gave emphasis toward the hyperlipidemic, pancreatic cells lipid peroxidation, and antioxidant activities which accentuate anti-diabetic prospects along with the probable mechanism(s) (Bagri et al., 2009). In the same way, the anti-diabetic screening of the methanolic extract of $P$. granatum seeds in streptozotocin-induced diabetic rats reflected $52 \%$ reduction $(135 \mathrm{mg} / \mathrm{dl})$ in blood glucose level at $600 \mathrm{mg} / \mathrm{kg}$ dose after 12 hours time (Das et al., 2001). A conclusion may be drawn from this study that the methanolic extracts presented a far better anti-hyperglycemic action than that of the reported hydroalcoholic extracts.

The ethanolic, chloroform, and butanolic extract of C. ternatea flower and leaves displayed potential pancreatic regeneration activity, anti-hyperlipidemic activity, and antidiabetic activity by valuable increase in the HDL-cholesterol, glucokinase, glycolytic enzyme, liver and skeletal muscle glycogen, and glucose-6-phosphatase; significantly modulating glycosylated hemoglobin, total cholesterol, triglycerides, urea, creatinine, alkaline phosphatase, aspartate aminotransferase, and alanine aminotransferase levels; prevents renal damage; and considerable reduction in the serum glucose level from 550 to $220 \mathrm{mg} / \mathrm{dl}$ in streptozotocin-induced diabetic rats for 14 days treatment (Daisy and Rajathi, 2009; Daisy et al., 2009; Kalyan et al., 2011; Talpate et al., 2013 ; Verma et al., 2013). The alkaloids, carbohydrates, glycosides, flavonoids, tannins, and saponins present in the various extract forms played an imperative role in exhibiting anti-hyperlipidemic and anti-diabetic activity. The methanolic combined extracts of $C$. ternatea and P. granatum produced a profound decrease in the blood glucose level within 6 hours of duration as compared to single extract which exhibited analogous results in 12 hours.

\section{CONCLUSION}

The research demonstrated that the combination of dried flower powders of $C$. ternatea and $P$. granatum exhibited a significant anti-hyperglycemic effect after 5 hours of oral administration. The phytoconstituents present in the plant material; primarily the flavonoids and alkaloids play a crucial role in mediating the pharmacological activity. This study will open new perspectives of future research in developing novel herbal formulations for the management of diabetes mellitus at the clinical level.

\section{REFERENCES}

Askary-Ashtiani A, Ghanjal A, Motaqi M, Meftahi GH, Hatef $\mathrm{B}$, Niknam H. The isokinetic and electromyographic assessment of knee muscles strength in the short-and long-term type 2 diabetes. Asian J Sport Med, 2016; 7(4):e37008.

Bagri P, Ali M, Aeri V, Bhowmik M, Sultana S. Antidiabetic effect of Punica granatum flowers: effect on hyperlipidemia, pancreatic cells lipid peroxidation and antioxidant enzymes in experimental diabetes. Food Chem Toxicol, 2009; 47(1):50-4.
Borikar SP, Kallewar NG, Mahapatra DK, Dumore NG, Danao KR. Combined flower decoction of Clitoria ternatea and Punica granatum expressed comparable hypoglycemic activity with that of metformin: in vivo study. Int J Pharm Science Res, 2017; 2(5):4-7.

Borikar SP, Kallewar NG, Mahapatra DK, Gupta RA, Dumore NG, Danao KR, et al. Decoction of Andrographis paniculata whole plant and Gymnema sylvestre leaves demonstrated noteworthy hypoglycemic activity in Sprague Dawley rat. Phytopharmacol J, 2018; 7(1):84-7.

Chhajed SS, Chaskar S, Kshirsagar SK, Haldar GA, Mahapatra DK. Rational design and synthesis of some PPAR- $\gamma$ agonists: substituted benzylideneamino-benzylidene-thiazolidine-2, 4-diones. Comp Biol Chem, 2017; 67:260-5.

Daisy P, Rajathi M. Hypoglycemic effects of Clitoria ternatea Linn. (Fabaceae) in alloxan-induced diabetes in rats. Trop J Pharm Res, 2009; 8(5):393-8.

Daisy P, Santosh K, Rajathi M. Antihyperglycemic and antihyperlipidemic effects of Clitoria ternatea Linn. in alloxan-induced diabetic rats. Afr J Microbiol Res, 2009; 3(5):287-91.

Das S, Barman S. Antidiabetic and antihyperlipidemic effects of ethanolic extract of leaves of Punica granatum in alloxan-induced noninsulin-dependent diabetes mellitus albino rats. Indian J Pharmacol, 2012; 44(2):219-24

Das AK, Mandal SC, Banerjee SK, Sinha S, Saha BP, Pal M. Studies on the hypoglycaemic activity of Punica granatum seed in streptozotocin induced diabetic rats. Phytother Res, 2001; 15(7):628-9.

Godbole MD, Mahapatra DK, Khode PD. Fabrication and characterization of edible jelly formulation of stevioside: a nutraceutical or OTC aid for the diabetic patients. Inventi Nutraceut, 2017; 2017(2):1-9.

Huang TH, Peng G, Kota BP, Li GQ, Yamahara J, Roufogalis BD, Li Y. Anti-diabetic action of Punica granatum flower extract: activation of PPAR- $\gamma$ and identification of an active component. Toxicol Appl Pharmacol, 2005; 207(2):160-9.

Jafri MA, Aslam M, Javed K, Singh S. Effect of Punica granatum Linn.(flowers) on blood glucose level in normal and alloxaninduced diabetic rats. J Ethnopharmacol, 2000; 70(3):309-14.

Kalyan BV, Kothandam H, Palaniyappan V, Praveen AR Hypoglycaemic activity of seed extract of Clitoria ternatea Linn in streptozotocin-induced diabetic rats. Pharmacognosy J, 2011; 3:45-7.

Kamble MA, Mahapatra DK, Dhabarde DM, Ingole AR. Pharmacognostic and pharmacological studies of Bombax ceiba thorn extract. J Pharm Pharmacog Res, 2017; 5(1):40-54.

Kanhed AA, Mehere AP, Pandey KR, Mahapatra DK 4-(2-chloroacetamido) Benzoic acid derivatives as local anesthetic agents design, synthesis, and characterization. UK J Pharm Biosci, 2016; 4(6):35-44.

Kavitha R, Premalakshmi V. Studies on the synergetic effect of Trichosanthes dioica and Clitoria ternatea leaf extract on the streptozotocininduced diabetic rats. Int J Res Pharm Biomed Sci, 2012; 3(3):1056-64.

Khalil EA. Antidiabetic effect of an aqueous extract of Pomegranate (Punica granatum L.) peels in normal and alloxan diabetic rats. Egyptian J Hospital Med, 2004; 16(1):92-9.

Kuhite NG, Padole CD, Amdare MD, Jogdand KR, Kathane LL, Mahapatra DK. Hippuric acid as the template material for the synthesis of a novel anti-diabetic 1,3,4-thiadiazole derivative. Indian J Pharm Biol Res, 2017; 5(3):42-5.

Li Y, Wen S, Kota BP, Peng G, Li GQ, Yamahara J, et al. Punica granatum flower extract, a potent $\alpha$-glucosidase inhibitor, improves postprandial hyperglycemia in Zucker diabetic fatty rats. J Ethnopharmacol, 2005; 99(2):239-44.

Mahapatra DK, Asati V, Bharti SK, Chalcones and their therapeutic targets for the management of diabetes: structural and pharmacological perspectives. Eur J Med Chem, 2015; 92:839-65.

Mahapatra DK, Bharti SK. Drug design. Tara Publications Private Limited, New Delhi, India, 2016.

Mahapatra DK, Bharti SK. Handbook of research on medicinal chemistry: innovations and methodologies. Apple Academic Press, New Jersey, 2017. 
Mahapatra DK, Bharti SK. Medicinal chemistry with pharmaceutical product development. Apple Academic Press, New Jersey, 2019.

Mahapatra DK, Chhajed SS, Shivhare RS. Development of murrayanine-chalcone hybrids: an effort to combine two privilege scaffolds for enhancing hypoglycemic activity. Int J Pharm Chem Anal, 2017; 4(2):30-4.

Radhika S, Smila KH, Muthezhilan R. Antidiabetic and hypolipidemic activity of Punica granatum Linn on alloxan induced rats. World J Med Sci, 2011; 6(4):178-82.

Sharma AK, Majumder M. Some observations on the effect of Clitoria Ternatea Linn on changes in serum sugar level and small intestinal mucosal carbohydrases activities in alloxan diabetes. Calcutta Med J, 1990; 87(11-12):168-71.

Talpate KA, Bhosale UA, Zambare MR, Somani R. Antihyperglycemic and antioxidant activity of Clitorea ternatea Linn. on streptozotocin-induced diabetic rats. Ayu, 2013; 34(4):433-39.
Verma PR, Itankar PR, Arora SK. Evaluation of antidiabetic antihyperlipidemic and pancreatic regeneration, potential of aerial parts of Clitoria ternatea. Rev Bras Farmacogn, 2013; 23(5):819-29.

How to cite this article:

Borikar SP, Kallewar NG, Mahapatra DK, Dumore NG. Dried flower powder combination of Clitoria ternatea and Punica granatum demonstrated analogous anti-hyperglycemic potential as compared with standard drug metformin: In vivo study in Sprague Dawley rats. J App Pharm Sci, 2018; 8(11): 075-079. 